\title{
Potensi dan Status Kerusakan Tanah di Kabupaten Kutai Timur
}

\author{
Muli Edwin ${ }^{1}$, Harmi Suptrapti ${ }^{2}$, Veronika Murtinah ${ }^{3}$, Liris Lis Komara ${ }^{4}$, dan Mufti \\ Perwira Putra ${ }^{5}$ \\ 1,3,4,5 Program Studi Kehutanan, STIPER Kutai Timur, Jalan Sukarno-Hatta 01, \\ Sangatta, Kutai Timur, Kaltim \\ 2 Dinas Lingkungan Hidup Kutai Timur, Kaltim \\ ${ }^{1}$ email: muli.edwin@yahoo.com
}

\begin{abstract}
Soil degradation to support the growth and development of plants and production of goods and services has become a global concern. Indonesia government has issued regulations related to the potential, status and damage of soil quality standards for biomass production. In order to support government programs and efforts to land improvement role and cooperation of researchers with local governments should be increased to multiply and information related to the potential for soil degradation can be used as supporting data for development planning in an area. Potential and status of soil degradation in the region of East Kutai Regency is still relatively low. But it has a high potential for damage, because land use more increasing for various purposes and the natural condition of soil in East Kalimantan dominated by old soil, such as Podsolic or Ultisols easily damaged if utilized without regard to principles of conservation. Especially for soil in Rantau Pulung there is a parameter with exceeded status of standard quality, ie permeability, then in Batu Ampar founded four parameters, namely permeability, composition of soil fraction, bulk density and soil $\mathrm{pH}$, next to Long Mesangat founded two parameters, namely bulk density and permeability. The more of limiting factor, then in the land use should also apply and demanding high conservation treatment to maintain or improve the land or soil quality.
\end{abstract}

Keywords: Soil, Degradation, Potencies, Conservation

\begin{abstract}
ABSTRAK
Degradasi tanah untuk mendukung pertumbuhan dan perkembangan tumbuhan serta menghasilkan barang dan jasa telah menjadi perhatian global. Pemerintah Indonesia telah mengeluarkan peraturan terkait potensi, status dan baku mutu kerusakan tanah untuk produksi biomassa. Dalam rangka mendukung program pemerintah dan upaya perbaikan lahan maka peran dan kerjasama peneliti bersama pemerintah daerah harus ditingkatkan untuk menggali informasi terkait potensi dan status kerusakan tanah yang dapat digunakan sebagai data pendukung untuk perencanaan pembangunan di suatu daerah. Potensi dan status kerusakan tanah di wilayah Kabupaten Kutai Timur masih tergolong rendah. Tetapi memiliki potensi tinggi terhadap kerusakan tanah, karena semakin meningkatnya pemanfaatan lahan untuk berbagai kepentingan dan kondisi alami tanah Kalimantan Timur yang merupakan tanah tua, yiatu podsolik merah kuning atau ultisols yang mudah terdegredasi apabila didayagunakan tanpa memperhatikan prinsip-prinsip konservasi. Khusus untuk lahan di Rantau Pulung terdapat satu parameter dengan status melebihi baku mutu, yaitu permeabilitas tanah, kemudian di Batu Ampar ditemukan empat parameter, yaitu permeabilitas, komposisi fraksi tanah, kerapatan lindak dan $\mathrm{pH}$ tanah, selanjutnya di Long Mesangat ditemukan dua parameter, yaitu kerapatan lindak dan permeabilitas. Semakin banyak faktor pembatas tersebut, maka dalam pemanfaatan lahan seharusnya juga menerapkan dan menuntut perlakuan konservasi yang tinggi untuk mempertahankan atau meningkatkan kualitas lahan atau tanah.
\end{abstract}

Kata kunci: Tanah, Degradasi, Potensi, Konservasi

\section{Pendahuluan}

Degradasi lahan atau tanah merupakan masalah global yang dapat menimbulkan dampak negatif pada mata pencaharian dan keamanan pangan, terutama petani di negaranegara berkembang (Lee dkk., 2014). Populasi dunia masa depan akan selalu membutuhkan persediaan makanan, yang mana sekitar 99,7\% makanan manusia untuk 
memenuhi kebutuhan kalori berasal dari tanah, sementara kurang dari $0,3 \%$ berasal dari lautan dan ekosistem air lainnya (FAO, 1998). Mempertahankan dan menambah pasokan pangan dunia pada dasarnya tergantung pada produktivitas dan kualitas tanah. Penurunan kualitas tanah dapat mengurangi produktivitas alam, pertanian, dan kehutanan. Tanah juga berperan penting untuk tingkat keanekaragaman tumbuhan, hewan dan mikroba dalam tanah (Pimentel, 2006). Tanah merupakan lapisan yang menyelimuti bumi dengan ketebalan bervariasi. Lapisan tersebut sebenarnya tidak berarti bila dibandingkan dengan massa bumi. Namun demikian, dari tanah inilah segala makhluk hidup yang berada di muka bumi baik tumbuhan maupun hewan memperoleh segala kebutuhan mineralnya (Sukisno dkk., 2011).

Penggalian informasi tentang tanah di Kalimantan Timur sangat penting. Kaltim dengan luas $211.440 \mathrm{~km}^{2}$ merupakan aset penting bagi pembangunan nasional terutama pembangunan yang bertalian dengan pendayagunaan tanah (Ruhiyat, 1999). Kabupaten Kutai Timur dengan luas wilayah 35.747,50 km² yang terdiri atas 18 kecamatan merupakan aset penting dalam pembangunan daerah. Pembangunan Kutai Timur bertumpu pada pertanian dalam arti luas dan pengembangan agribisnis yang mana luas lahan perkebunan sebesar 892 580,59 ha dan luas lahan pertanian 46 265,79 ha (BPS Kutai Timur, 2014) akan memegang peranan penting untuk mewujudkan visi pembangunan. Informasi terkait tingkat kerusakan tanah dan potensinya masih belum banyak diteliti dan dipelajari secara komprehensif, sehingga diperlukan program konservasi lahan dan tanah dengan penggalian informasi tentang kondisi lahan termasuk tingkat kerusakan tanah terutama pada lahan pertanian dan perkebunan masyarakat.

Degradasi lahan telah menjadi masalah penting sepanjang sejarah, dan telah mencapai skala global saat ini (Diamond, 2005; Lee dkk., 2014). Pemerintah Indonesia telah mereatifikasi terkait hal tersebut dengan mengeluarkan Peraturan Pemerintah Republik Indonesia Nomor 150 Tahun 2000 tentang Pengendalian Kerusakan Tanah untuk Produksi Biomassa dan Peraturan Menteri Negara Lingkungan Hidup Nomor 07 Tahun 2006 tentang Tata Cara Pengukuran Kriteria Baku Kerusakan Tanah untuk Produksi Biomassa. Kedua peraturan tersebut menjadi acuan dalam penelitian ini. Menurut Sukisno dkk., (2011), bahwa terpetakannya potensi dan status kerusakan tanah dapat ditentukan tindakan pengelolaan tanah dan lahan yang sesuai sehingga kerusakan tanah dapat dicegah atau diperbaiki.

\section{Metode Penelitian}

Lokasi pelaksanaan kegiatan penelitian untuk penyusunan status dan potensi kerusakan tanah meliputi tiga kecamatan, Kecamatan Long Mesangat, Batu Ampar dan Rantau Pulung. Metode yang digunakan dalam kegiatan ini adalah metode survei fisiografi 
terpilih, yaitu dengan melakukan pengamatan dan pengambilan sampel tanah secara langsung di lapangan yang lokasinya secara sengaja dipilih. Sampel tanah dianalisis di laboratorium tanah fakultas pertanian Universitas Mulawarman. Pengambilan sampel tanah dilakukan pada lokasi yang telah ditentukan berdasarkan peta kerja. Sampel untuk keperluan analisis laboratorium diambil $1 \mathrm{~kg}$ sampel tanah secara komposit dan sampel tanah tidak terganggu untuk setiap satuan lahan pengamatan.

Analisis data untuk penyusunan potensi kerusakan tanah disusun dengan prosedur overlay mengacu pada PERMENLH nomor 7 Tahun 2006. Data dianalisis untuk memperoleh informasi mengenai potensi kerusakan tanah. Analisis spasial dilakukan dengan menumpangsusunkan (overlay) beberapa data spasial (parameter penentu potensi kerusakan tanah), sehingga diperoleh unit peta baru yang akan digunakan sebagai unit analisis. Pada setiap unit analisis tersebut dilakukan analisis terhadap data atributnya berupa data tabular. Hasil analisis tabular selanjutnya dikaitkan dengan data spasialnya untuk menghasilkan data spasial potensi kerusakan tanah.

Metode yang digunakan dalam analisis tabular adalah metode skoring. Pada unit analisis hasil tumpangsusun data spasial dilakukan dengan menjumlahkan skor. Hasil penjumlahan skor digunakan untuk klasifikasi penentuan tingkat potensi kerusakan tanah. Klasifikasi tingkat kerusakan tanah untuk produksi biomassa menurut penjumlahan skor dengan parameter kerusakan tanah digunakan untuk mengelompokkan terhadap akumulasi tematik berdasarkan Tabel 1 berikut ini.

Tabel 1. Kriteria kelas potensi kerusakan tanah menurut jumlah skor

\begin{tabular}{ccc}
\hline Simbol & Potensi kerusakan tanah & Skor Pembobotan \\
\hline PR. I & Sangat rendah & $<15$ \\
PR. II & Rendah & $15-24$ \\
PR. III & Sedang & $25-34$ \\
PR. IV & Tinggi & $35-44$ \\
PR. V & Sangat Tinggi & $45-50$ \\
\hline
\end{tabular}

PR: Potensi Kerusakan

Tabel 2. Evaluasi status kerusakan tanah di lahan kering

\begin{tabular}{|c|c|c|c|c|}
\hline No. & Parameter & $\begin{array}{l}\text { Ambang Kritis } \\
\text { (PP 150/2000) }\end{array}$ & $\begin{array}{c}\text { Hasil } \\
\text { Pengamatan/Analisa }\end{array}$ & Melebihi/Tidak \\
\hline 1 & Ketebalan Solum & $<20 \mathrm{~cm}$ & $\mathrm{~cm}$ & \\
\hline 2 & Kebatuan Permukaan & $>40 \%$ & $\%$ & \\
\hline 3 & Komposisi Fraksi & $\begin{array}{c}<18 \% \text { koloid; } \\
>80 \% \text { pasir } \\
\text { kuarsitik }\end{array}$ & $\%$ & \\
\hline 4 & Berat isi & $>1,4 \mathrm{~g} / \mathrm{cm}^{3}$ & $\mathrm{~g} / \mathrm{cm} 3$ & \\
\hline 5 & Porositas Total & $<30 \% ;>70 \%$ & $\%$ & \\
\hline 6 & Derajat Pelulusan Air & $\begin{array}{l}<0,7 \mathrm{~cm} / \mathrm{jam} \\
>8,0 \mathrm{~cm} / \mathrm{jam}\end{array}$ & $\mathrm{cm} / \mathrm{jam}$ & \\
\hline 7 & $\mathrm{pH}\left(\mathrm{H}_{2} \mathrm{O}\right) 1: 2,5$ & $<4,5 ;>8,5$ & & \\
\hline 8 & $\begin{array}{l}\text { Daya Hantar Listrik/ } \\
\text { DHL }\end{array}$ & $>4,0 \mathrm{mS} / \mathrm{cm}$ & $\mathrm{mS} / \mathrm{cm}$ & \\
\hline 9 & Potensial Redoks & $<200 \mathrm{mV}$ & $\mathrm{mV}$ & \\
\hline 10 & Jumlah Mikrobia & $\begin{array}{c}<10^{2} \mathrm{cfu} / \mathrm{g} \\
\text { tanah }\end{array}$ & $\mathrm{cfu} / \mathrm{g}$ tanah & \\
\hline
\end{tabular}


Selanjutnya untuk menentukan status kerusakan tanah pada lahan kering, dilakukan dengan metode determinasi sesuai dengan parameter dan ambang batas yang telah ditetapkan dalam peraturan (Tabel 2). Apabila salah satu ambang parameter terlampaui, maka tanah yang dievaluasi dapat dikatakan rusak.

\section{Hasil dan Pembahasan}

Lahan merupakan suatu lingkungan fisik yang meliputi tanah, iklim, relief, hidrologi dan vegetasi, yang mana faktor-faktor tersebut mempengaruhi potensi dan menjadi pembatas dalam pendayagunaannya. Sebagai contoh, suatu lahan yang kualitasnya sesuai untuk pertanian, maka lahan tersebut semestinya dimanfaatkan untuk pertanian (Klingiebel dan Montgomery 1961; Hardjowigeno dan Widiatmaka 2007). Perubahan sifat atau karakteristik tanah atau lahan dalam hubungannya dengan produksi biomassa dapat disebabkan oleh berbagai hal seperti, tindakan pengolahan tanah yang tidak memperhatikan kaedah konservasi, pemupukan yang berlebihan, pemanfaatan lahan yang terus-menerus dalam waktu yang lama atau pemanfaatan lahan yang tidak sesuai dengan kemampuan dari lahan itu sendiri.

\section{Kondisi Umum Lingkungan Studi}

Dalam sistem fisiografi atau bentang alam dipengaruhi oleh faktor internal dan eksternal. Faktor internal penting yang mempengaruhi fisik kawasan yaitu litologi, sedangkan faktor eksternal yang penting yaitu iklim termasuk didalamnya adalah curah hujan, suhu rata-rata, dan bulan basah serta bulan kering. Faktor internal seperti litologi berpengaruh terhadap tanah di atasnya terutama pada sifat fisik dan kimia tanah. Litologi merupakan penyusun fisiografi yang secara langsung menjadi batuan induk tanah yang terbentuk melalui proses pelapukan. Kondisi fisik tanah seperti warna, tekstur, konsistensi, permeabilitas, porositas dan drainase internal tanah sangat dipengaruhi oleh batuan induknya. Demikian juga sifat kimia tanah sangat dipengaruhi oleh komposisi mineral dan senyawa kimia yang menyusun batuan induk tersebut (Subroto, 2004). Berdasarkan informasi geologi dari data sekunder RePPProT (1987) dapat diketahui bahwa bahan induk yang berperan dalam pembentukan tanah di daerah studi merupakan batuan sedimen.

Daerah survei merupakan suatu kawasan yang terletak di bagian tengah, pulau Kalimantan. Berdasarkan data sekunder daerah tersebut tersusun dari batuan endapan (sedimen) seperti batu pasir dan batu sabak, kebanyakan formasi sedimen relatif muda dan mencakup batu bara dan batuan yang mengandung minyak bumi. Kondisi tanah merupakan faktor terpenting yang mempengaruhi penyebaran vegetasi dan pola bercocok tanam. Sebagian besar tanah di Kalimantan Timur berkembang pada dataran bergelombang dan pegunungan yang tertoreh dari batuan sedimen dan batuan beku tua. Kondisi tanah di Kalimantan pada umumnya tidak subur untuk kegiatan usaha pertanian 
(JICA, 1998), sehingga lahan daratan tersebut memerlukan upaya atau sistem konservasi yang tepat dan sesuai karena terdiri atas lahan rawa, gambut, lahan bertanah asam, berpasir dan lahan yang memiliki kelerengan curam.

Topografi wilayah Kabupaten Kutai Timur bervariasi berupa daratan landai, bergelombang hingga berbukit-bukit dan pegunungan serta pantai, dengan ketinggian tempat juga bervariasi antara 0-7 $\mathrm{m}$ hingga lebih dari $1.000 \mathrm{~m}$ dari permukaan laut (dpl). Wilayah dengan dataran mencapai $46 \%$, pegunungan 30\%, perbukitan $16 \%$ dan lainnya mencapai 8\% (BAPPEDA Kutai Timur, 2011). Di antara variasi yang dimaksud adalah:

a. Kawasan yang relatif datar dan landai terdapat di Kecamatan Sangatta, Muara Bengkal, Muara Ancalong dan sebagian Muara Wahau serta Sangkulirang yang sangat sesuai untuk dikembangkan menjadi areal permukiman dan pertanian, industri berat, pengembangan tanaman keras dan kawasan prioritas untuk pengembangan lapangan terbang.

b. Kawasan pegunungan kapur terdapat di daerah Kecamatan Sangkulirang, Kongbeng, Karangan, Bengalon, Kaliorang dan Sandaran yang cocok untuk pengembangan pertanian terbatas seperti jati, karet dan lainnya.

c. Jaringan sungai terdapat di hampir seluruh kecamatan terutama Sungai Sangatta, Sungai Marah dan Sungai Wahau. Sungai-sungai di daerah ini airnya dimanfaatkan penduduk sekitar sebagai sumber air minum dan jalur transportasi air antara daerah pantai dan daerah pedalaman.

d. Danau terdapat di Kecamatan Muara Bengkal yaitu Danau Ngayau dan Danau Karang. Wilayah pantai yang berada di sebelah timur kabupaten mempunyai ketinggian antara 0-7 $\mathrm{m}$ dpl. Wilayah ini mempunyai sifat kelerengan datar, mudah tergenang rawa dan merupakan daerah endapan.

Pembentukan tanah di Kalimantan Timur banyak dipengaruhi oleh iklim (curah hujan) dan topografi, karena Kaltim merupakan wilayah tropis yang selalu terjadi hujan sepanjang tahun. Curah hujan yang tinggi di Kaltim dapat mempercepat proses pelapukan, yaitu dikarenakan suhu dan kelembapan. Karena curah hujan yang tinggi, tanah selalu basah dan unsur-unsur pokoknya yang dapat larut hilang, proses ini disebut pelindian. Tingkat pelapukan, pelindian dan kegiatan biologi (kerusakan bahan-bahan organik) yang tinggi merupakan ciri berbagai tanah di Kalimantan (Burnham, 1984). Tanah yang mengalami pelapukan sangat berat ini membentuk jenis tanah podsolik merah-kuning (USDA: Ultisols) di sebagian besar daratan Kalimantan yang bergelombang. Pada daerah pinggiran sungai, danau dan pantai terbentuk tanah baru seperti entisols, inceptisols dan organosols serta histosols. Sebagaimana tergambar pada Gambar 1, daerah Batu Ampar lebih banyak memiliki lahan yang bergelombang dengan kelerengan 16-25\% dibandingkan dua kecamatan, yaitu Long Mesangat dan Rantau Pulung. 


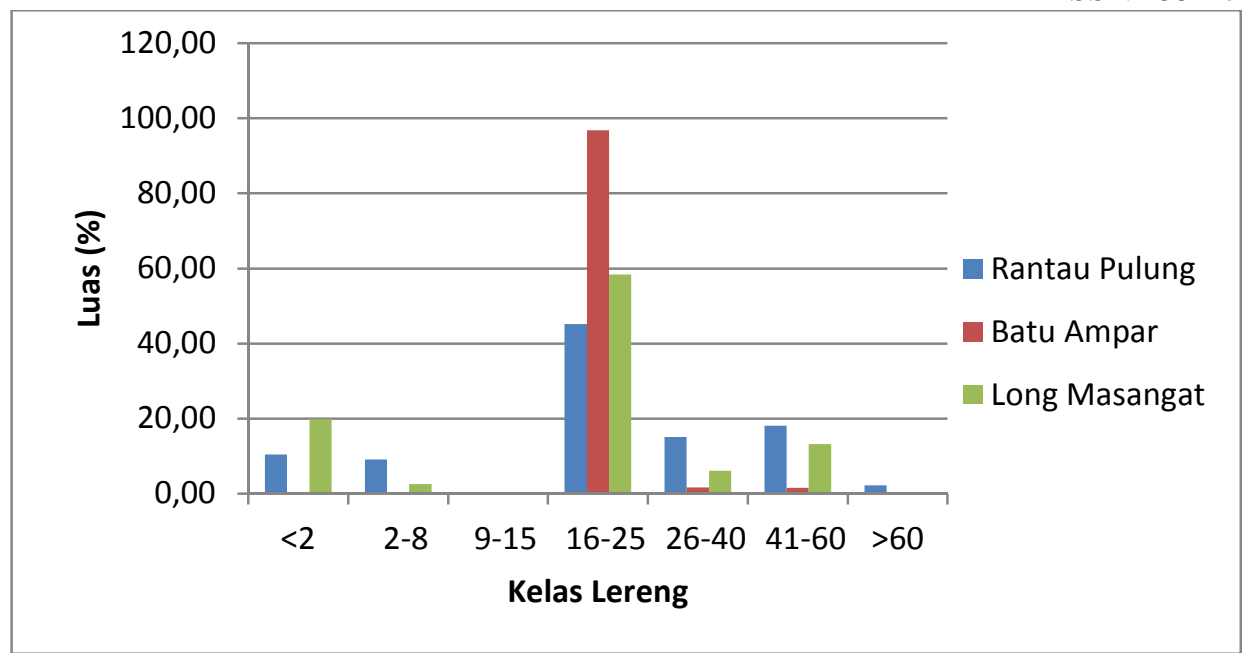

Gambar 1. Persentase luas daerah berdasarkan tingkat kelerengan

Di daerah hutan hujan tropis jumlah curah hujan per tahun berkisar antara 1600 sampai dengan $4000 \mathrm{~mm} /$ thn (Warsito, 1999) dengan sebaran bulan basah 9,5-12 bulan basah (Sanches, 1992). Hujan selain berfungsi sebagai sumber air juga berfungsi sebagai sumber hara. Whitmore (1986) menyatakan bahwa banyak nitrogen yang terfiksasi selama terjadi badai dan turun ke bumi bersama dengan hujan. Hara lain yang banyak masuk ke dalam ekosistem melalui curah hujan menurut adalah $\mathrm{K}, \mathrm{Ca}$, dan $\mathrm{Mg}$. Walaupun memberi dampak positif bagi produktivitas vegetasi menurut Resosoedarmo dkk. (1986) curah hujan yang tinggi akan menyebabkan tanah-tanah yang tidak tertutupi oleh vegetasi rentan sekali terhadap pencucian yang akan mengurangi kesuburan tanah dengan cepat. Barbour dkk. (1987) menyatakan bahwa pencucian adalah penyebab utama hilangnya hara dari suatu ekosistem. Hara yang mudah sekali tercuci terutama adalah Ca dan K (Wiharto, 2006). Wilayah Kabupaten Kutai Timur yang merupakan wilayah khatulistiwa mempuyai curah hujan yang sangat tinggi sehingga wajar wilayah tersebut telah mengalami pencucian tingkat lanjut dan didominasi oleh ordo atau jenis tanah-tanah tua seperti ultisols.

\section{Kondisi Fisik dan Kimia Tanah Daerah Studi}

Dari hasil analisis sifat fisik dan kimia tanah di daerah studi yaitu Kecamatan Rantau Pulung, Batu Ampar dan Long Mesangat dapat diketahui status karakteristik fisika tanah sebagai berikut ini.

Tabel 3. Kondisi fisika tanah daerah studi

\begin{tabular}{l|c|c|c|c|c|c|c}
\hline \multirow{2}{*}{ Kecamatan } & \multirow{2}{*}{$\begin{array}{c}\text { Porositas } \\
(\%)\end{array}$} & $\begin{array}{c}\text { Permeabilitas } \\
(\mathrm{cm} / \mathrm{jam})\end{array}$ & $\begin{array}{c}\text { Kerapatan Lindak } \\
\left(\mathrm{g} / \mathrm{cm}^{3}\right)\end{array}$ & \multicolumn{4}{|c}{ Tekstur tanah $(\%)$} \\
\cline { 5 - 8 } & & & Liat & Debu & Pasir & Kelas \\
\hline Rantau Pulung & 40,17 & 0,0078 & 1,39 & 29,2 & 54,7 & 16,1 & SiCL \\
\hline Batu Ampar & 42,24 & 0,0088 & 1,43 & 30,5 & 39,9 & 29,6 & $\mathrm{CL}$ \\
\hline Long Mesangat & 42,65 & 0,0073 & 1,43 & 17,5 & 47,7 & 34,8 & $\mathrm{~L}$ \\
\hline
\end{tabular}

Ket: SiCL : Lempung berpasir; CL : Lempung berliat; L : Lempung

Kandungan fraksi tanah (tekstur) sangat mempengaruhi konsistensi tanah atau keeratan tanah. Tanah yang bertekstur pasir sulit menyerap (menahan) air dan unsur hara, sedangkan tanah yang bertekstur liat memiliki kemampuan besar menyerap air dan unsur 
hara. Persentase fraksi tanah juga memiliki kemampuan untuk menahan dari tumbukan air hujan dan penghayutan oleh aliran air tanah (run-off).

Menurut Hardjowigeno (2003), tanah yang memiliki nilai KTK rendah memiliki kemampuan yang rendah untuk menjerap dan menyediakan unsur hara bagi tanaman. Tanah-tanah tua seperti Ultisols yang sebarannya terbanyak di Kalimantan Timur umumnya mempuyai KTK rendah. Prasetyo dan Suriadikarta (2006), menyatakan bahwa tanah ultisols merupakan tanah yang sebarannya luas di Indonesia dan sebaran terluas terdapat di Kalimantan (21.938.000 ha). Untuk Kalimantan Timur sebaran tanah ultisols sekitar 10,04 juta ha atau sekitar $80 \%$ dari luas daratan Kaltim. Berdasarkan kesuburan kimiawi tanah di daerah studi tergolong tanah kurang subur, tetapi memiliki kandungan bahan organik C (\%) yang relatif tinggi. Hal tersebut menunjukkan bahan organik atau cadangan carbon tanah relatif tinggi. Keuntungan dari tingginya bahan organik di dalam tanah adalah dapat memperbaiki sifat fisik tanah dan menambah jumlah dan jenis organisme/mikroba di tanah. Berdasarkan hasil analisis laboratorium jumlah mikroba baik bakteri dan jamur di dalam tanah cukup tinggi seperti disajikan dalam tabel berikut ini.

Tabel 4. Jumlah mikroba, redoks dan DHL di daerah studi

\begin{tabular}{lcccc}
\hline \multirow{2}{*}{ Kecamatan } & \multicolumn{4}{c}{ Parameter } \\
\cline { 2 - 5 } & \multicolumn{2}{c}{ Jumlah mikroba } & $\begin{array}{c}\text { Redoks } \\
(\mathrm{cfu} / \mathrm{g} \text { tanah) }\end{array}$ & $\begin{array}{c}\mathrm{DHL} \\
(\mathrm{mS} / \mathrm{cm})\end{array}$ \\
\cline { 2 - 5 } & Bakteri & Jamur & & \\
\hline Rantau Pulung & $1,2 \times 10^{5}$ & $5,0 \times 10^{3}$ & 301 & 0,059 \\
\hline Batu Ampar & $6,6 \times 10^{4}$ & $8,0 \times 10^{3}$ & 375 & 0,053 \\
\hline Long Mesangat & $1,3 \times 10^{5}$ & $6,0 \times 10^{3}$ & 240 & 0,257 \\
\hline Ket : cfu : colony forming units & & &
\end{tabular}

Banyaknya jumlah mikroba di dalam tanah sangat penting peranannya untuk membantu dan mempercepat proses dekomposisi secara biokimia yang hasilnya berupa kompos. Proses dekomposisi dapat terganggu atau terhambat bila tanah dalam kondisi anaerob (tergenang air). Di daerah studi yang meliputi tiga kecamatan hanya di Kecamatan Long Mesangat yang memiliki sebagian kecil dari luas keseluruhan yang merupakan daerah dataran rendah dan rawa, sedangkan dua kecamatan merupakan daerah perbukitan bergelombang.

\section{Potensi dan Status Kerusakan Tanah}

Meningkatnya berbagai usaha dan atau kegiatan manusia yang dapat menimbulkan pencemaran air, pencemaran udara, kerusakan lahan dan atau tanah, serta meningkatnya pengaduan masyarakat terkait adanya dugaan pencemaran dan/ atau perusakan lingkungan hidup, maka diperlukan pengelolaan lingkungan hidup yang optimal agar masyarakat mendapatkan kualitas lingkungan hidup yang baik dan sehat. Oleh karena itu, Pemerintah Daerah Kabupaten perlu memberikan pelayanan dasar sesuai dengan standar pelayanan minimal bidang lingkungan hidup. Sumberdaya alam khususnya tanah pada prinsipnya merupakan sumberdaya alam yang dapat diperbaharui, namun mudah mengalami kerusakan atau degradasi. 
Dari laporan Badan Lingkungan Hidup Tahun 2013 potensi kerusakan tanah di wilayah Kabupaten Kutai Timur terbesar pada status sedang, yaitu sekitar $67 \%$ dari luas keseluruhan wilayah Kutai Timur. Kemudian status kerusakan tinggi hanya sekitar $5 \%$ dari luas keseluruhan wilayah (BLH Kutai Timur, 2013)

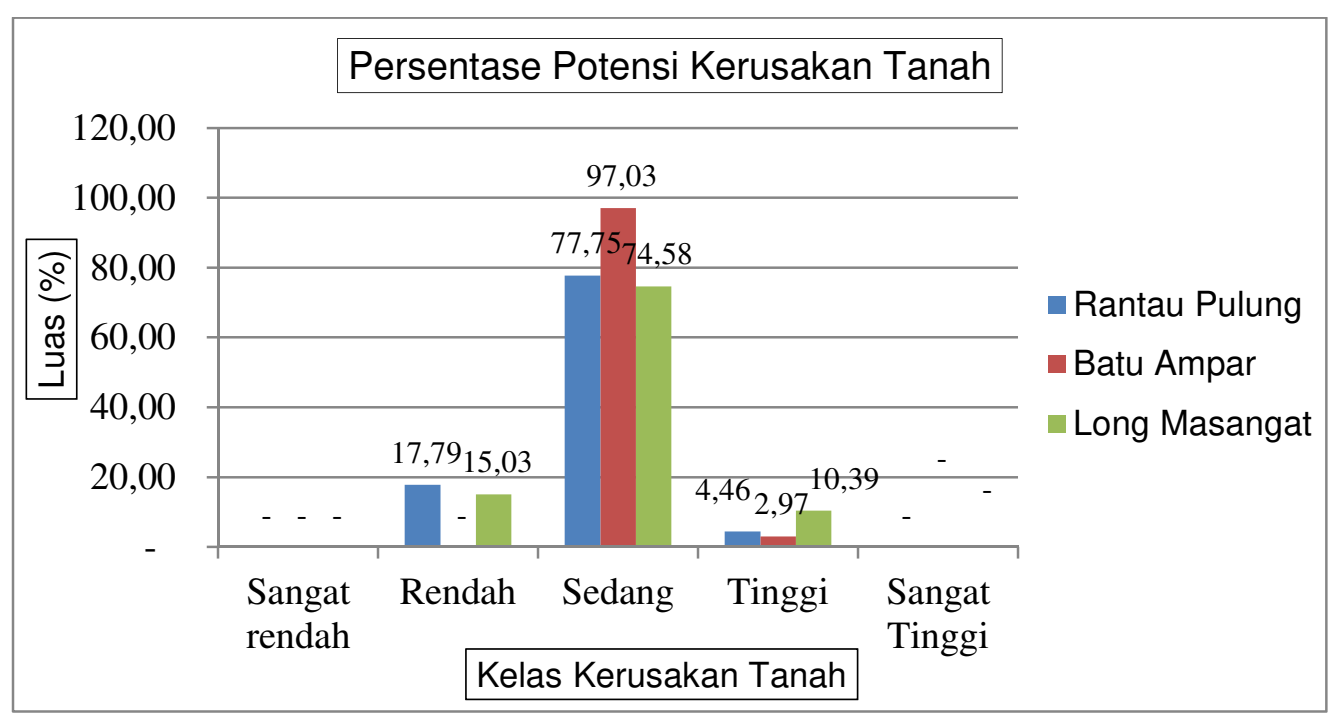

Gambar 2. Luas potensi kerusakan tanah di daerah studi

Dari grafik di atas (Gambar 2) menunjukkan ketiga daerah memiliki kerusakan tertinggi pada status sedang, dan Kecamatan Batu Ampar yang paling besar, yaitu sekitar 97,03\%. Hal tersebut menjadi wajar karena karakteristik lahan di Batu Ampar memiliki tingkat kelerengan yang lebih curam dibanding Rantau Pulung dan Long Mesangat. Selain itu penggunaan lahan di Batu Ampar sebagian besar bekas HPH (Hak Penguasaan Hutan). Berdasarkan status kerusakan hutan produksi memang memiliki bobot yang tinggi dibanding lahan semak belukar, kebun campuran dan hutan.

Daerah Rantau Pulung sekitar $77,75 \%$ dengan status kerusakan sedang dan sebagian kecil sekitar 6,97\% kerusakan tinggi. Kerusakan tinggi terdistribusi di daerah pertambangan batu bara, yaitu PT Kaltim Prima Coal. Kemudian Long Mesangat memiliki potensi sekitar 10,39\% dengan status tinggi, karena sebagian besar daerah tersebut, yaitu $80 \%$ merupakan kawasan budidaya yang banyak dimanfaatkan untuk berbagai kepentingan seperti perkebunan kelapa sawit, pertanian tanaman semusim dan budidaya lainnya. Selain itu luas lahan terbuka juga cukup tinggi dengan curah hujan yang relatif tinggi dibanding Kecamatan Rantau Pulung dan Batu Ampar.

Kawasan Areal Penggunaan Lain (APL) merupakan kawasan budidaya yang secara intensif lahannya dimanfaatkan untuk berbagai kegiatan seperti perkebunan, pemukiman, pertanian, peternakan, fasilitas publik dan pemanfaatan lainnya yang memiliki potensi tinggi terhadap laju tingkat kerusakan tanah. Analisis sebaran potensi kerusakan pada kawasan budidaya ini (APL) didasarkan pada asumsi bahwa pada lahan dalam kawasan lindung, Kawasan Suaka Alam (KSA) dan Kawasan Pelestarian Alam (KPA) relatif aman dari 
kerusakan tanah. Berdasarkan kriteria pembobotan nilai, bahwa budidaya tanaman semusim atau monokultur dan tanah terbuka ternyata memiliki nilai skor yang paling tinggi dibanding tipe penggunaan lahan lainnya.

Kerusakan lingkungan hidup termasuk kerusakan tanah atau lahan dapat diartikan sebagai proses deteriorasi atau penurunan mutu (kemunduran) lingkungan. Deteriorasi lingkungan ini ditandai dengan hilangnya sumberdaya tanah, air, udara, punahnya flora dan fauna liar, dan kerusakan ekosistem. Pada tahun 2004, High Level Threat Panel, Challenges and Change PBB, memasukkan degradasi lingkungan sebagai salah satu dari sepuluh ancaman terhadap kemanusiaan. Kerusakan lingkungan juga menjadi salah satu faktor penting yang menentukan tinggi rendahnya risiko bencana di suatu kawasan. Penyebab kerusakan lingkungan hidup secara umum bisa dikategorikan dalam dua faktor yaitu akibat peristiwa alam dan akibat ulah manusia (IPCC, 2000).

Penilaian untuk mengetahui status kerusakan tanah di daerah studi dilakukan pada areal budidaya yang merupakan areal yang langsung dikelola oleh masyarakat. Dari hasil penilaian status kerusakan tanah untuk produksi biomassa pada tahun 2015 terhadap tiga kecamatan dikemukakan pada Tabel 5 berikut ini.

Tabel 5. Hasil evaluasi status kerusakan tanah di daerah studi

\begin{tabular}{|c|c|c|c|c|}
\hline \multirow{2}{*}{ No. } & \multirow{2}{*}{ Parameter } & \multicolumn{3}{|c|}{ Keterangan Ambang Batas } \\
\hline & & Batu Ampar & Long Mesangat & Rantau Pulung \\
\hline 1 & Ketebalan Solum & Tidak & Tidak & Tidak \\
\hline 2 & Kebatuan Permukaan & Tidak & Tidak & Tidak \\
\hline 3 & Komposisi Fraksi & Melebihi & Tidak & Tidak \\
\hline 4 & Berat isi & Melebihi & Melebihi & Tidak \\
\hline 5 & Porositas Total & Tidak & Tidak & Tidak \\
\hline 6 & $\begin{array}{l}\text { Derajat Pelulusan Air/ } \\
\text { permeabilitas tanah }\end{array}$ & Melebihi & Melebihi & Melebihi \\
\hline 7 & $\mathrm{pH}\left(\mathrm{H}_{2} \mathrm{O}\right) 1: 2,5$ & Melebihi & Tidak & Tidak \\
\hline 8 & Daya Hantar Listrik/ DHL & Tidak & Tidak & Tidak \\
\hline 9 & Potensial Redoks & Tidak & Tidak & Tidak \\
\hline 10 & Jumlah Mikroba & Tidak & Tidak & Tidak \\
\hline
\end{tabular}

masyarakat. Dari tabel tersebut menunjukkan hanya permeabilitas tanah yang nilainya melebihi batas baku mutu. Hal tersebut bisa terjadi karena memang sifat alami dari tanah yang mana tanah yang bertekstur liat cendrung sulit melewatkan air. Kemudian untuk daerah Batu Ampar merupakan areal budidaya tanaman tahunan yang diusahakan oleh masyarakat berupa kebun lada. Areal tersebut memiliki tingkat kelerengan yang curam, sehingga menjadi wajar beberapa parameter melebihi ambang baku mutu seperti parameter komposisi fraksi, berat isi, permeabilitas dan $\mathrm{pH}$ tanah.

Selanjutnya di daerah Long Mesangat terdapat dua parameter yang melebihi baku mutu yaitu kerapatan lindak dan permeabilitas. Areal survei merupakan kebun karet yang diusahakan oleh masyarakat, karena sebagian besar areal disana memang banyak dimanfaatkan untuk budidaya tanaman tahunan seperti karet. Ketiga lokasi (kecamatan) 
memiliki permasalahan yang hampir sama terkait status kerusakan tanah, yaitu macam tanah atau ordo tanah yang dimiliki merupakan tanah tua yaitu ultisols. Tanah tersebut memiliki sebaran yang paling luas di Kaltim merupakan tanah tua dengan tingkat kesuburan yang rendah dan telah mengalami tingkat pencucian lanjut.

\section{Kesimpulan}

Di Rantau Pulung potensi kerusakan lahan adalah sekitar 118.591,86 ha, dan di kawasan APL yang berpotensi sekitar 45.771,07 ha dengan status rendah sampai tinggi. Potensi kerusakan lahan secara keseluruhan adalah sekitar 50.854,15 ha, sedangkan di APL adalah 8.339,04 ha dengan status rendah sampai tinggi. Setelah dilakukan verifikasi lapangan kawasan budidaya di Rantau Pulung terdapat satu parameter dengan status melebihi baku mutu, yaitu permeabilitas tanah, kemudian di Batu Ampar ditemukan ada empat parameter, yaitu permeabilitas, komposisi fraksi tanah, kerapatan lindak dan $\mathrm{pH}$ tanah, selanjutnya di Long Mesangat ditemukan parameter kerapatan lindak dan permeabilitas.

\section{Daftar Pustaka}

Barbour, C.A., J.H. Burk \& W. D. Pitt. (1987). Terrestrial Plant Ecology. The Benjamin Cunnings Publishing Company.

BAPPEDA Kutai Timur. (2011). RPJMD Kutai Timur 2011-2015. Pemerintah Kabupaten Kutai Timur, Sangatta.

BPS Kutai Timur. (2014). Kutai Timur Dalam Angka. Pemerintah Kabupaten Kutai Timur, Sangatta.

BLH Kutai Timur. (2013). Identifikasi Kerusakan Tanah untuk Produksi Biomassa. Laporan Akhir. Badan Lingkungan Hidup Kabupaten Kutai Timur, Sangatta.

BPS Kutai Timur. (2014). Kutai Timur dalam Angka. Badan Pusat Statistik Kabupaten Kutai Timur, Sangatta.

Diamond, J. (2005). Collapse: How Societies Choose to Fail or Ducceed. Viking, New York, NY.

FAO. (1998). The State of Food and Agriculture. Food and Agriculture Organization of The United Nation. Rome, Italy.

Hardjowigeno, S. (2003). Klasifikasi Tanah dan Pedogenesis. Akademika Pressindo, Jakarta.

Hardjowigeno, S. \& Widiatmaka. (2007). Kesesuaian Lahan dan Perencanaan Tataguna Lahan. Gajah Mada University Press. Yogyakarta.

IPCC. (2000). Land use, Land-Use Change and Forestry. In: Watson, R.T., Noble, I.R., Bolin, B., Ravindranath, N.H., Verardo, D., Dokken, D. (Eds.), A Special Report of the Intergovernmental Panel on Climate Change. Cambridge University Press, Cambridge.

Lee, Q.B, E. Nkonya \& A. Mirzabaev. (2014). Biomass Productivity-Based Mapping of Global Land Degradation Hotspots. ZEF-Discussion Papers on Development Policy 
No. 193. Zentrum für Entwicklungsforschung (ZEF), Center for Development Research. Bonn, Germany. pp.57 h.

Peraturan Pemerintah Republik Indonesia Nomor 150 Tahun 2000 tentang Pengendalian Kerusakan Tanah untuk Produksi Biomassa. 23 Desember 2000. Lembaran Negara Nomor 267, Jakarta.

Peraturan Menteri Negara Lingkungan Hidup Nomor 07 Tahun 2006 tentang Tata Cara Pengukuran Kriteria baku Kerusakan Tanah untuk Produksi Biomassa. Kedua peraturan tersebut menjadi acuan dalam penelitian ini. 22 Agustus 2006. Lembaran Negara Nomor 07, Jakarta.

Pimental, D. (2006). Soil Erosion: A Food and Environmental Threat. Environment, Development and Sustainability 8: 119-137.

Prasetyo, B.H. \& D.A. Suriadikarta. (2006). Karakteristik, Potensi dan Teknologi Pengelolaan Tanah Ultisol untuk Pengembangan Pertanian Lahan Kering di Indonesia. Balai Besar Penelitian dan Pengembangan Sumberdaya Lahan Pertanian. Jurnal Litbang, Bogor.

Ruhiyat, D. (1999). Potensi Tanah di Kalimantan Timur Karakteristik dan Strategi Pendayagunaannya. Fakultas Kehutanan. Univeristas Mulawarman, Samarinda.

Soil Survey Staff. (1999). Soil Taxonomy. United States Department of Agriculture, Natural Resources Conservation Service. Government Printing Office, Washington, D.C.

Subroto. (2004). Geomorfologi dan Analisis Landscape. Fajar gemilang, Samarinda.

Sukisno, K. S. Hindarto, Hasanudin \& A. H. Wicaksono. (2011). Pemetaan Potensi dan Status Kerusakan Tanah untuk Mendukung Produktivitas Biomassa di Kabupaten Lebong. Prosiding Seminar Nasional Budidaya Pertanian. Bengkulu 7 Juli 2011. hal: 140-157.

Wiharto, M. (2006). Produktivitas Vegetasi Hutan Hujan Tropis. http://naturehealthy.webs.com/produktivitas_hht.pdf, Tanggal 2 Mei 2010. 